\title{
Lipid biomarkers and their specific carbon isotopic compositions of cold seep carbonates from the South China Sea
}

Lu Ge ${ }^{\mathrm{a}, \mathrm{c}}$, Shao-Yong Jiang ${ }^{\mathrm{b}, \mathrm{c}^{*}}$ Martin Blumenberg ${ }^{\mathrm{d}, \mathrm{e}}$, Joachim Reitner ${ }^{\mathrm{d}}$,

${ }^{a}$ Institute of Isotope Hydrology, School of Earth Sciences and Engineering, Hohai University, Nanjing 210098, China

${ }^{\mathrm{b}}$ State Key Laboratory of Geological Processes and Mineral Resources, Faculty of Earth Resources, China University of Geosciences, Wuhan 430074, China

${ }^{\mathrm{c}}$ State Key Laboratory for Mineral Deposits Research, Department of Earth Sciences, Nanjing University, Nanjing 210093, China

d Department of Geobiology, Centre for Geosciences, Georg-August-University of Göttingen, Germany

e present address: Federal Institute for Geosciences and Natural Resources (BGR), Stilleweg 2, 30655 Hannover, Germany.

Correspondences should be addressed to Professor Shao-Yong Jiang (email: shyjiang@cug.edu.cn; shyjiang@nju.edu.cn)

\begin{abstract}
Cold seep carbonates were studied from two locations (Dongsha and Chiasian) in the northern South China Sea and on Taiwan island. Lipid biomarkers and their stable carbon isotopic compositions extracted from these seep carbonate samples were analyzed in this study and the results pointed at the anaerobic oxidation of methane (AOM) as responsible for carbonate formation. Distinct AOM communities were indicated by isotopically highly depleted archaeal biomarkers (with $\delta^{13} \mathrm{C}$ values as low as $-140.8 \%$ VPDB) and bacterial biomarkers (with $\delta^{13} \mathrm{C}$ values as low as $-128.6 \%$ VPDB), which confirmed that biogenic methane was the dominant carbon source. Lipid biomarker distributions indicated that ANME-2 archaea were
\end{abstract}


prevalent in sample TVG3-C2g from Dongsha and sample JX8 from Chiasian. In addition, differences of the AOM communities between the carbonates appeared to be caused by the respective biogeochemical environments. ANME-1 archaea tended to be abundant in high-Mg calcite carbonates, and their formation might be linked to low methane fluxes. In contrast, ANME-2 consortia were prevalent in aragonite carbonates and appeared to have prospered at sites with high methane supply. Our data imply that the mineralogy of the seep carbonates precipitated in the northern South China Sea appears to be influenced by the distinct ANME consortia, which are induced by methane flux.

Keywords: Lipid biomarkers; Cold seep carbonates; Anaerobic oxidation of methane; Microbial communities; The South China Sea

\section{Introduction}

The anaerobic oxidation of methane $(\mathrm{AOM})$ is one of the major sinks of this greenhouse gas in marine environments and hence is a significant process in the global carbon cycle and methane budget (e.g., Barnes and Goldberg, 1976; Valentine, 2002; Blumenberg et al., 2004; Reeburgh, 2007). At seep sites, AOM, which is mediated by methane oxidizing archaea in a syntrophic consortium with sulphate reducing bacteria (SRB) (e.g., Hinrichs et al., 1999; Boetius et al., 2000; Pancost et al., 2000; Orphan et al., 2001; Michaelis et al., 2002; Reitner et al., 2005), is responsible for an increase in alkalinity that favors the precipitation of authigenic carbonates (Ritger et al., 1987; Peckmann et al., 2001). Previous investigations have shown that three anaerobic methanotroph clusters exist (ANME-1, -2, -3), which are distantly related to methanogens of the orders Methanomicrobiales and Methanosarcinales (Boetius et al., 2000; Orphan et al., 2001; Blumenberg et al., 2004; Niemann et al., 2006; Niemann and Elvert, 2008). Most of the relevant archaea are assigned to two phylogenetic distinct clusters, termed ANME-1 and ANME-2, which usually exit together with SRB of the Seep-SRB1 cluster, belonging to the Desulfosarcina/Desulfococcus group (DSS) (Boetius et al., 2000; Orphan et al., 2001; 
Niemann et al., 2006).

The identification of AOM communities was achieved by independent, molecular techniques, i.e. 16S rDNA clone libraries and/or fluorescence in situ hybridisation (FISH), as well as lipid biomarker analyses (Hinrichs et al. 1999, Boetius et al. 2004, Michaelis et al., 2003). A number of studies revealed that lipid biomarkers combined with their compound specific stable carbon isotopes provided detailed information on microbial activity associated with seepage (e.g., Boetius et al., 2000; Pancost et al., 2000; Orphan et al., 2001; Michaelis et al., 2002; Xu et al., 2014). The molecular fingerprints of the chemosynthesis based on microbial communities at methane seeps tend to be not only present in modern authigenic carbonates but is often also extremely well preserved in ancient cold seep environments (Thiel et al., 1999; Peckmann et al., 1999; Peckmann \& Thiel, 2004; Birgel and Peckmann, 2008). Numerous studies provided detailed information on specific molecular biomarker inventories associated with methane seep environments. However, ecological parameters selecting for a particular AOM community are not yet fully understood, but possibly depends on parameters such as temperature, methane flux and oxygen partial pressures (Boetius et al., 2000; Blumenberg et al., 2005; Nauhaus et al. 2005; Knittel \& Boetius, 2009).

AOM seep locations are globally distributed and numerous sites have also been described from the northern South China Sea. The main focus of respective studies on those cold seep carbonates was on their geochemical signatures, including mineralogy, petrology, and stable oxygen and carbon isotopes (Chen et al., 2005; Chen et al., 2006; Han et al., 2008; Ge et al., 2010; Tong et al., 2013). Although ${ }^{13} \mathrm{C}$-depleted lipid biomarkers have been found in sediments and authigenic carbonates in this area (Birgel et al., 2008; Yu et al., 2008; Ge et al., 2011; Guan et al., 2013), little is known on the distribution of AOM communities and factors favoring specific consortia. In this paper, we report on the lipid biomarkers and their specific carbon isotopic compositions of cold seep carbonates from two locations (Dongsha and Chiasian) in the northern South China Sea and on Taiwan island. By analyzing the distribution of biosignatures of anaerobic methanotrophs, our study intends to gain particularly 
information on the biogeochemical environmental factors controlling the diversity and distribution of AOM communities in seep carbonates from the South China Sea.

\section{Geologic setting}

The modern South China Sea is a Cenozoic, Atlantic-type marginal sea in the west Pacific and was established under the interactions of Eurasian, Pacific and India-Australian plates. It is underlain by oceanic basement dotted with volcanic structures, which developed deep-reaching faults along their flanks and upwards through the sediment column (Han et al., 2008). Since the Mesozoic, the northern continental margin went through a succession of geotectonic regimes and formed NE-SW extending faults (Chen et al., 2006). Accordingly, the Taiwan orogeny resulted from an oblique arc-continent collision between the Philippine Sea Plate and the Eurasian Plate since the Late Mesozoic (Huang et al., 2000, 2001). The accretionary prism east the Manila Trench changed its structural trend when it approached Taiwan, and finally exposed northward as the Western Foothills, which is part of the offshore Taiwan Basin (Huang et al., 2006). Many cold seeps are distributed on the northern passive continental margin of the South China Sea (Xisha Trough, Shenhu area, and Dongsha Islands) and on the Western Foothills on Taiwan island (e.g., Chen et al., 2005; Chen et al., 2006; Huang et al., 2006; Han et al., 2008; Ge et al., 2010, 2011; Chien et al., 2012; Tong et al., 2013). Our study areas from southwest to northeast are Shenhu, Dongsha and Chiasian (Fig. 1).

Shenhu is located in the southeastern Pearl River Mouth Basin, adjacent to several large oil and gas fields with thick sediments rich in organic matter and an unusually high concentration of methane (Ge et al., 2010; Sun et al., 2014). Deep-reaching faults and diapirs widely develop that serve as methane-rich fluid pathways (Fig. 1C). Gas hydrate was firstly recovered in this area at 153-225 m below the seafloor in 2007 (Zhang et al., 2007). Already in 2004, a cruise of the research vessel Haiyangsihao trawled cold seep carbonate chimneys from site HS4DG at a water depth of 350-400 m (Fig. 1A; Table 1).

Dongsha is located at the transition between the passive northern margin and the 
accretionary eastern margin off SW Taiwan Island (Suess et al., 2005; Han et al., 2008). The seafloor morphology is characterized by NE-SW extending Dongsha rise and shelf depression area (Fig. 1C). The widespread tectonic faults, folds and volcanic diapirs are possible main conduit system of methane fluid transporting from depth up to the shallow sediment (Suess et al., 2005; Chen et al., 2006). In 2004, during a joint Chinese-German cruise RV Sonne (cruise 177) discovered hundreds of seep carbonates from Site 1, Site 2 and Site 3 using TV guided grabs (Fig. 1A; Table 1; Suess et al., 2005; Han et al., 2008).

Chiasian is located $60 \mathrm{~km}$ NE Taiwan in the southern Western Foothills (Fig. 1B). The strata of this area are best exposed along the Nantszuhien River (Chung, 1962). The lowest sequence is the middle Miocene upper slope mudstone, which is covered conformably by the Late Miocene shallow-marine storm-dominant sandstones, and was finally overlain by the Plio-Pleistocene foreland mudstone (Chung, 1962; Ting et al., 1991; Sung et al., 2000). The geological structure of the Chiasian area can primarily be represented by an imbricate fault system. In addition to major thrusts (the Chiasian Fault) and folds, several faults which trend northwest are right-lateral strike-slip faults (Fig. 1B). Methane-derived carbonates of various size and shape are embedded in the thick mudstone of the early Pliocene Yenshuikeng Formation near the Nantszuhien River, which deposited in upper slope south of Asian continental shelf.

Fig.1. Geological map of the study areas in the northern part of the South China Sea and Chiasian on Taiwan (B after Chung, 1962; Ting et al., 1991; Sung et al., 2000; C after Chen et al., 2006).

\section{Methods}

\subsection{Mineralogical and stable carbon isotope analyses}

Bulk mineralogy was determined by X-ray diffraction on pressed powder mounts using a diffractometer with $\mathrm{CuK} \alpha$ radiation (Philips PW 1830). Data were collected from 3 to $70^{\circ} 2 \theta$ using a step size of $0.02^{\circ} 2 \theta$. Samples for carbon isotope analyses 
were carefully subsampled by a microdrill. Extraction of $\mathrm{CO}_{2}$ was liberated using pure phosphoric acid at $75^{\circ} \mathrm{C}$ in an online GasBench II device connected to a Finnigan Delta Plus XP. Replicate analyses of a laboratory standard showed an analytical precision better than $0.15 \%$ for $\delta^{13} \mathrm{C}$. The $\delta^{13} \mathrm{C}$ results were reported relative to VPDB standard.

\subsection{Lipid biomarker analyses}

\subsubsection{Extraction and fractionation}

The chemical workup including preparation, decalcification, saponification and extraction of lipid biomarkers was modified after Heller et al. (2012). A total of $100 \mathrm{~g}$ ground samples were dissolved by $10 \% \mathrm{HCl}$ for decalcification. The residue was centrifuged and saponified in $6 \% \mathrm{KOH}$ in methanol. The samples were subjected $3 \mathrm{x}$ with $n$-hexane using ultrasonication to extract neutral lipids including alcohols and hydrocarbons. Extracts were combined and concentrated in a precleaned rotary evaporator, followed by reduction of the solvent to near dryness in a stream of $\mathrm{N}_{2}$. The resulting total extracts were further separated by column chromatography (Merck silica gel 60) and eluents of increasing polarity ( $n$-hexane, DCM, methanol), providing a hydrocarbon fraction (F1) and a polar fraction (F2; containing alcohols). The polar fraction was treated with bis (trimethylsiyly) trifluoroacetamide (BSTFA) to convert alcohols into trimethylsilylethers. The extraction residue after saponification was acidified with $10 \% \mathrm{HCl}$ to $\mathrm{pH} 1-2$ and again extracted with $n$-hexane (to extract fatty acids). Fatty acids were converted to their methyl esters by adding trimethylchlorosilane (TMCS) in methanol before analysis (FA).

\subsubsection{Gas chromatography-mass spectrometry (GC-MS) and GC-combustion isotope ratio mass spectrometry (GC-C-IRMS)}

The hydrocarbons (F1) and alcohols (F2) as well as the fatty acids (FA) were analyzed using GC-MS (Varian CP-3800 chromatograph coupled to a 1200L mass spectrometer). The MS was operated in electron impact mode with $70 \mathrm{eV}$ (source temperature $200^{\circ} \mathrm{C}$ ). The system was equipped with a fused silica capillary column (Phenomenex ZB5-MS, $30 \mathrm{~m}, 0.25 \mu \mathrm{m}$ film thickness, i.d. $0.32 \mathrm{~mm}$, He as carrier 
gas). Compounds were identified by comparing mass spectra and retention times with published data and/or reference compounds (Niemann and Elvert, 2008).

The compound specific $\delta^{13} \mathrm{C}$ values were analyzed using a Thermo Scientific Trace GC coupled to a Delta Plus isotope-ratio MS. The combustion reactor contained $\mathrm{CuO}, \mathrm{Ni}$, and $\mathrm{Pt}$ and was operated at $940^{\circ} \mathrm{C}$. The stable carbon isotopic compositions are reported vs. VPDB standard. All the measurements were carried out at Geoscience center, Georg-August-University Göttingen.

\section{Results}

\subsection{Geochemical characteristics}

Two samples from two locations (Chiasian and Dongsha) are selected for biomarker study (Table 1). Sample JX8 from Chiasian is a small chimney of about 13 $\mathrm{cm}$ in diameter (Fig. 2A). This type of small isolate developed in perpendicular to beddings. It is filled with recrystallized calcite in the core which was likely representing the conduit of venting. Besides clay minerals and terrigenous quartz and feldspar, the rim part mostly consists of dolomite and few bioclasts (Table 2). Isotopic signature demonstrated ${ }^{13} \mathrm{C}$ depletions (-24.0\%, Table 2). The second sample used for biomarker analyses is TVG3-C2g from Site 1, Dongsha area (Fig. 1C; Table 1). It is an irregular porous crust with dark brown coating (Fig. 2B). The sample is mainly composed of aragonite and is characterized by an extremely low $\delta^{13} \mathrm{C}$ value $(-50.9 \%$, Table 2).

Fig.2. Images of the seep carbonate samples from Chiasian (A) and Dongsha (B).

\subsection{Hydrocarbons}

The $n$-alkanes comprising $\mathrm{C}_{14}$ to $\mathrm{C}_{33}$ were the major compounds in the hydrocarbon fractions of TVG3-C2g and JX8 (Fig.3). In the latter sample, contents decrease slightly with increasing chain length, with the exception of $n-\mathrm{C}_{23}$. The most prominent carbon skeletons were tail-to-tail linked isoprenoidal structures. Crocetane (2,6,11,15-tetramethylhexadecane) was most likely present coeluting with phytane. 
Other tail-to-tail linked isoprenoids pentamethyleicosane (PMI) and the tentative contaminant squalene were prevalent in samples JX8 and TVG3-C2g (Fig.3). The $\mathrm{C}_{30}$ hopanoid diploptene was only identified in sample TVG3-C2g.

The $\delta^{13} \mathrm{C}$ values varied from strong (-42.0\%) to extreme ${ }^{13} \mathrm{C}$ depletions as low as $-106.9 \%$ (PMI) in sample JX8. The most ${ }^{13} \mathrm{C}$ depleted compound in sample TVG3-C2g was also PMI with $-140.8 \%$. The $\delta^{13} \mathrm{C}$ values of $n-\mathrm{C}_{23}$ varied from $-55.2 \%$ to $-54.7 \%$ in two samples (Table 3 ).

Fig.3. Total ion current (TIC) chromatograms of hydrocarbons from samples TVG3-C2g and JX8. Black dots: $n$-alkanes; Pr: pristane; Cr: crocetane; Ph: phytane; PMI: pentamethyleicosane.

\subsection{Alcohols}

Fig.4 shows a representative GC-MS chromatogram of the alcohol fraction obtained from sample TVG3-C2g. The $n$-alcohols were predominant, ranging from $n-\mathrm{C}_{14}$ to $n-\mathrm{C}_{28}$. Phytanol and cholesterol are present in sample. Ether lipids other than Archaeol (Ar) and sn2-hydroxyarchaeol (sn2-OH-Ar), monoalkyl glycerol ethers (MAGEs) and dialkyl glycerol ethers (DAGEs), were also found. A small amount of iso-/anteiso- $\mathrm{C}_{15}$ and $\mathrm{C}_{16}$ MAGEs, as well as sn3-phytanyl-MAGE were observed. Among DAGEs, DAGE I e, I d, and I f described in Pancost et al. (2001) were found. These compounds exhibited extremely depleted $\delta^{13} \mathrm{C}$ values ranging from $-81.9 \%$ to $-128.6 \%$ (Table 3 ). Ar and $s n 2-\mathrm{OH}-\mathrm{Ar}$ also showed very low $\delta^{13} \mathrm{C}$ values (-134.3\%o and $-129.0 \%$, respectively).

Neither Ar and sn2-OH-Ar, nor MAGEs and DAGEs were observed in sample JX8 (chromatogram not shown).

Fig.4. Total ion current (TIC) chromatogram of alcohols from sample TVG3-C2g. Black dots: n-alcohols; S: sugar derivatives; MAGE: monoalkyl glycerol ether; DAGE: dialkyl glycerol diether; sn2-OH-Ar: sn2-hydroxyarchaeol.

\subsection{Fatty acids}


Short chain $n$-fatty acids, ranging from $n-\mathrm{C}_{12}$ to $n$ - $\mathrm{C}_{18}$, predominated in sample TVG3-C2g and JX8 (Fig.5). The even-numbered $n$-fatty acids were more abundant than adjacent odd-numbered ones, and peaked at $n-\mathrm{C}_{16}$. The $i$ so- $\mathrm{C}_{15}$ fatty acid $\left(\delta^{13} \mathrm{C}=\right.$ $-48.3 \%$ to $-37.0 \%$ ) and anteiso- $\mathrm{C}_{15}$ fatty acid $\left(\delta^{13} \mathrm{C}=-60.6 \%\right.$ to $-49.4 \%$ ) showed moderate ${ }^{13} \mathrm{C}$ depletions (Table 3). The $17 \alpha(\mathrm{H}), 21 \beta(\mathrm{H})-32$-hopanoic acid and $17 \beta(\mathrm{H}), 21 \beta(\mathrm{H})-32$-hopanoic acid were present in trace amounts in sample TVG3-C2g and JX8. Due to their low concentrations, no stable carbon isotope values could be obtained.

Fig.5. Total ion current (TIC) chromatogram of fatty acids from sample JX8. Black dots: $n$-fatty acids.

\section{Discussion}

\subsection{Identification of archaeal and bacterial communities by biomarkers in South} China Sea seep carbonates

Archaeal biomarkers at AOM sites include (1) $\mathrm{C}_{20}$ and $\mathrm{C}_{25}$, irregular tail-to-tail linked, isoprenoidal hydrocarbons, e.g. crocetane and PMI and their unsaturated homologues; (2) isoprenoidal glycerol ethers, such as $\mathrm{Ar}$ and $s n 2-/ s n 3-/ d i-h y d r o x y a r c h a e o l$. Typifying bacterial biomarkers are fatty acids and alkyl glycerol ethers. Alkyl glycerol ethers, most likely derived from SRB involved in $\mathrm{AOM}$, encompass MAGEs and DAGEs. If ${ }^{13} \mathrm{C}$-depleted, these lipid biomarkers are regarded as the evidence of AOM (Niemann and Elvert, 2008).

A suite of specific ${ }^{13} \mathrm{C}$ depleted lipids demonstrating the presence of distinct consortia mediating AOM has been established (Blumenberg et al., 2004; Niemann and Elvert, 2008). The presence of strongly ${ }^{13} \mathrm{C}$ depleted crocetane appears to be a good marker for ANME-2 while in ANME-1 dominated settings an absence of crocetane is common. The ${ }^{13} \mathrm{C}$ depleted PMI is considered to be the most common AOM biomarker in methane-seep deposits (Elvert et al., 1999; Peckmann and Thiel, 2004). Strongly ${ }^{13} \mathrm{C}$ depleted $\mathrm{Ar}$ and sn2-OH-Ar were universal in AOM habitat at cold seeps (Koga et al., 1998; Hinrichs et al., 1999; Boetius et al., 2000; Pancost et al., 
2001). The ratio of sn2-OH-Ar/Ar, however, was proposed as a specific fingerprint pattern for either ANME-1 or ANME-2 (Blumenberg et al., 2004). This ratio ranges between 0 and 0.8 in systems clearly dominated by ANME-1, whereas higher ratios are indicative for a predominance of ANME-2 (Blumenberg et al., 2004; Niemann and Elvert, 2008).

According to these proxies, it is likely that ANME-2 is the most predominating archaea in sample TVG3-C2g, suggested by crocetane, PMI and sn2-OH-Ar/Ar ratio $>1$. The presence of crocetane and PMI in sample JX8 is diagnostic for ANME-2 archaea.

Biomarkers with strong depletion in ${ }^{13} \mathrm{C}$ of bacterial origin are also often found in AOM environments (e.g. Elvert et al., 2003; Blumenberg et al., 2004; Niemann and Elvert, 2008). Isotopically depleted $n-\mathrm{C}_{23}$ is an unusual hydrocarbon putatively derived from SRB involved in AOM at modern and ancient seep sites (Thiel et al., 2001; Birgel et al., 2006; Peckmann et al., 2009; Guan et al., 2013). Specific and reliable molecular fossils such as iso/anteiso- $\mathrm{C}_{15}$-fatty acids trace the presence of SRB at modern methane-seeps (e.g., Thiel et al., 2001; Elvert et al., 2003, 2005; Blumenberg et al., 2004). Besides the fatty acid pattern, typical compounds of the sulphate reducing AOM partners are ${ }^{13} \mathrm{C}$ depleted MAGEs and DAGEs (Hinrichs et al., 1999; Niemann and Elvert, 2008). MAGEs seem to be reliable markers of SRB because of their similar chain length distribution and unsaturation pattern compared to the co-occurring fatty acid fingerprint (Elvert et al., 2003). Previous studies showed that DAGEs might be synthesized by SRB occurring with ANME-1 and ANME-2 archaea in many AOM environments (Niemann and Elvert, 2008; Guan et al., 2013).

The presence of $n-\mathrm{C}_{23}$, fatty acids (isolanteiso- $\mathrm{C}_{15^{-}}$) together with MAGEs (iso-/anteiso-/ $\mathrm{C}_{16}-/$ sn3-phytanyl-) and MAGEs ( $\mathrm{I} \mathrm{e}, \mathrm{I} \mathrm{d}$, and I f) in sample TVG3-C2g reveals SRB participating in AOM and assimilating methane-derived carbon. In sample $\mathrm{JX} 8, n-\mathrm{C}_{23}$ and iso/anteiso- $\mathrm{C}_{15}$-fatty acids exhibit significantly low $\delta^{13} \mathrm{C}$ values, close to values of lipids derived from SRB (Thiel et al., 2001; Blumenberg et al., 2004; Birgel et al., 2006; Peckmann et al., 2009). In summary, bacterial lipid compounds are not exclusively restricted to a particular group of SRB 
in our discussion, but due to the identifying unequivocal ${ }^{13} \mathrm{C}$ depleted bacterial biomarkers, SRB are indicated as archaeal partners in AOM environments from the northern South China Sea. Moreover, other seven cold seep carbonates from the South China Sea have been reported on their biomarkers and specific carbon isotopes (Table 1; Yu et al., 2008; Birgel et al., 2008; Ge et al., 2011; Guan et al., 2013). The lipid compounds found in these carbonates suggested a clear predominance of ANME-1 in samples TVG7-15A, TVG8-V5, TVG13-C3, TVG14C-C2, TVG11-C2 and HS4DG, and ANME-2 consortia in TVG3C, respectively (Table 3).

\subsection{Carbon source of lipid biomarkers in South China Sea seep carbonates}

The sources of carbon in cold seep carbonates include (1) methane from biogenic methane $\left(\delta^{13} \mathrm{C}<-65 \%\right)$ to thermogenic sources $\left(\delta^{13} \mathrm{C}:-30 \%\right.$ - 50\%o $)$, (2) sedimentary organic carbon $\left(\delta^{13} \mathrm{C}=-20 \%\right.$ ), and (3) marine carbonate (0\%) (Aharon et al., 1997). The carbonate TVG3-C2g is characterized by strong negative as low as $-50.9 \%$ (Table 2), indicating that the carbon source is most probably biogenic methane-derived. The $\delta^{13} \mathrm{C}$ value $(-24.0 \%$ ) of sample $\mathrm{JX} 8$ is probably due to a significant source of carbon from methane mixed with relatively ${ }^{13} \mathrm{C}$-enriched sources. In addition, the highly depleted $\delta^{13} \mathrm{C}$ values $(-57.6 \%$ to $-35.7 \%$, Table 2 ) of other seven seep carbonates from the South China Sea suggest that most of the carbon was from methane turnover (Han et al., 2008; Ge et al., 2011; Tong et al., 2013).

Typifying archaeal biomarkers and bacterial biomarkers in samples TVG3-C2g and JX8 have strongly depleted $\delta^{13} \mathrm{C}$ values $(-140.8 \%$ $-42.0 \%$ and $-106.9 \%$ o $-37.0 \%$, respectively, Table 3), which are significantly lower than that of normal lipids in marine sediments $\left(\delta^{13} \mathrm{C}=-25 \%\right.$, Niemann and Elvert, 2008). The $\delta^{13} \mathrm{C}$ values of PMI range from $-140.8 \%$ o to $-106.9 \%$, agreeing well with a significant contribution from biogenic methane. The $\delta^{13} \mathrm{C}$ values $\left(-134.3 \% \%_{-12}-0 \%\right.$ ) of $\mathrm{Ar}$ and sn2-OH-Ar in sample TVG3-C2g, which are considerably lower than the range of methane-derived carbonates worldwide (Niemann and Elvert, 2008), indicate their origin from methane-oxidizing archaea. Fatty acids with $\delta^{13} \mathrm{C}$ values from $-60.6 \%$ o to $-37.0 \%$ in samples TVG3-C2g and JX8 reveal the incorporation of methane-derived carbon. 
Strongly ${ }^{13} \mathrm{C}$-depleted MAGEs I e, I d and I $\mathrm{f}$ in sample TVG3-C2g show that microbial communities utilized the carbon from methane. Their similar $\delta^{13} \mathrm{C}$ values as PMI, Ar and sn2-OH-Ar suggest that these components have the same carbon source. Tricosane was detected in the two studied samples, with $\delta^{13} \mathrm{C}$ values ranging from $-55.2 \%$ to $-54.7 \%$. These values are obviously lower than those of tetracosane $(-32.8 \%$ to $-31.2 \%$ ), suggesting the difference of carbon sources. Overall, the carbon isotopic compositions of these AOM biomarkers which are similar to the results of the typical cold seeps worldwide, confirm the biogenic methane carbon source.

Comparing with other seven seep carbonates from the South China Sea (Table 3), the carbon isotopic compositions of AOM biomarkers in cold seep carbonates from different areas share some common characteristics (Fig.6). Lipids contain both archaeal biomarkers and bacterial biomarkers at Shenhu area, Dongsha Islands and Chiasen seep sites. Hydrocarbons have a large range of $\delta^{13} \mathrm{C}$ values (except PMI) suggesting mixed carbon sources of these compounds. The carbon isotopic compositions of tricosane and fatty acids concentrate in a certain range (-60.6\% to $-32.5 \%$ ), revealing that the carbon was derived from methane mixed with relatively

${ }^{13} \mathrm{C}$-enriched sources. On the other hand, strongly ${ }^{13} \mathrm{C}$-depleted PMI, isoprenoidal glycerol ethers and DAGEs with $\delta^{13} \mathrm{C}$ values lower than $-80 \%$ are considered derived from biogenic methane.

Fig.6. Carbon isotopic compositions of AOM-related biomarkers in cold seep carbonates from Chiasian, Dongsha and Shenhu areas.

HS4DG data cited from Ge et al. (2011); TVG3C and TVG7-15A data cited from Yu et al. (2008); TVG14C-C2, TVG13C-C3 and TVG8-C5 date cited from Guan et al. (2013); TVG11-C2 data cited from Birgel et al. (2008).

\subsection{Distribution of ANME communities in South China Sea seep carbonates}

Distinct patterns of ${ }^{13} \mathrm{C}$-depleted lipid compounds display that cold seep carbonates from the northern South China Sea contain different microbial communities of archaea and SRB. Our study, together with other published data (Yu 
et al., 2008; Birgel et al., 2008; Ge et al., 2011; Guan et al., 2013), show that the methanotrophic archaea controlling the carbonate precipitation in the South China Sea are dominated by ANME-1 and ANME-2 (Fig.7). ANME-1 archaea appear to prevail in high-Mg calcite (HMC) samples while ANME-2 archaea are predominant in aragonite carbonates. Similar relationships between prevailing ANME and carbonate phases have been also observed in other AOM settings (Leefmann et al., 2008; Stadnitskaia et al., 2008; Birgel et al., 2011; Guan et al., 2013).

The prevalence of individual AOM consortia is indicative of multiple environmental and physiological factors (Blumenberg et al., 2004; Nauhaus et al., 2005; Elvert et al., 2005; Pape et al., 2005; Guan et al., 2013). The abundance of biomarkers was found to be related to average methane flux (Torres et al., 2002; Elvert et al., 2005). One factor inducing preferential growth of ANME-1 or ANME-2 communities is likely to be methane flux. It was observed that ANME-2 consortia are prevalent at assumingly high methane partial flux and pressure, while ANME-1 archaea are more adapted to lower methane supply (Blumenberg et al., 2004; Pape et al., 2005; Guan et al., 2013). Previous studies suggested that fluctuations in ion activity control the mineralogy of precipitates at methane seeps (Savard et al., 1996). The aragonite carbonates (TVG3-C2g, TVG3C, TVG7-15A, and TVG11-C2) precipitate in seawater with high alkalinity, high sulfate concentrations and high methane-charged fluids (Aloisi et al., 2000; Luff and Wallmann, 2003). This fact is consistent with the finding that ANME-2 consortia are favored in high methane flux (Blumenberg et al., 2004). In contrast, the HMC samples (TVG8-C5, TVG13-C3, and TVG14-C2) are tentatively precipitated at a low alkalinity and low sulfate environment through the activity of ANME-1, implying moderate supplies of methane. Moreover, ANME-1 archaea are believed to be more sensitive to oxygen than ANME-2 consortia (Elvert et al., 2005). This is consistent with the condition below the zone suitable for aragonite formation, where sulfate is locally exhausted by bacterial reduction within the sediment (Ritger et al., 1987; Stakes et al., 1999; Peckmann et al., 2001). Consequently, our observations on aragonite and HMC seep carbonates basically correspond to previous results, which indicate that ANME-2 
archaea consortia are more adaptable to higher methane fluxes compared to ANME-1 communities (Blumenberg et al., 2004; Elvert et al., 2005; Pape et al., 2005; Guan et al., 2013).

However, carbonate samples with dolomite as the major carbonate mineral show different ANME groups, with ANME-1 dominant in HS4DG and ANME-2 prevalent in JX8 (Fig.7). Pape et al (2005) pointed out that the shape of AOM-derived carbonates is crucially influenced by the respective methane supply. The chimneys are indicative of a vigorous flux, which is able to make pipe-like migration pathways (Stakes et al., 1999). This would be in good accordance with the observation that the dolomite chimney JX8 was dominated by ANME-2 with high methane flux. However, ANME-1 archaea is predominant in dolomite chimney HS4DG, which seems cannot be explained simply by relationships between ANME prevalence and methane supply. In this case, besides methane flux, the dominance of individual AOM consortia in dolomite samples could be controlled by multiple factors (Blumenberg et al., 2004; Elvert et al., 2005; Pape et al., 2005). Dolomite precipitation is enhanced by the removal of dissolved sulfate from pore-water with attendant increases in the alkalinity (Baker and Kastner, 1981; Aloisi et al., 2000). Morover, ANME-1 dominated consortia oxidize methane at lower cell specific rates than ANME-2 communities (Pape et al., 2005), which is in accord with the low content of organic matter in sample HS4DG (Ge et al., 2011). In this case, further investigations are needed to explore the factors controlling the prevalence of ANME community.

Fig.7. Distributions of ANME communities of cold seep carbonates from Chiasian, Dongsha and Shenhu areas.

Dol: dolomite; HMC: high-Mg-calcite; Ara: aragonite. HS4DG data cited from Ge et al. (2011); TVG3C and TVG7-15A data cited from Yu et al. (2008); TVG14C-C2, TVG13C-C3 and TVG8-C5 date cited from Guan et al. (2013); TVG11-C2 data cited from Birgel et al. (2008).

\section{Conclusions}


Cold seep carbonates were collected from the northern South China Sea and on Taiwan island. Distinct AOM communities were indicated by the occurrence of typifying archaeal and bacterial biomarkers. The strongly depleted ${ }^{13} \mathrm{C}$ signatures of AOM-related lipids and cold seep carbonates confirmed that biogenic methane was the dominant carbon source. Sample TVG3-C2g from Dongsha and sample JX8 from Chiasian revealed a likely dominance of ANME-2 archaea. Bacterial biomarkers with strong ${ }^{13} \mathrm{C}$ depletions confirmed the presence of sulfate-reducing bacteria participating in AOM. The high-Mg calcite carbonates precipitated at relatively low methane flux are dominated by ANME-1 archaea. ANME-2 consortia most likely mediated the precipitation of aragonite carbonates and appeared to prosper at sites of high methane supply. Therefore, the mineralogy of cold seep carbonates appears to be influenced by the distinct ANME consortia, which are induced by methane flux.

\section{Acknowledgments}

Funding for this research was provided by National Science Foundation of China (Grant No. 41203021) and the National Postdoctoral Foundation of China (Grant No. 2013M530231) and the Jiangsu Postdoctoral Sustentation Fund, China (Grant No. 1201061C) and the State Key Laboratory for Mineral Deposits Research Fund of China (Grant No. 17-1112-2). Martin Blumenberg thanks the German Research Foundation (DFG: Grant BL917/1-3).

\section{References}

Aloisi, G., Bouloubassi, I., Heijs, S.K., Pancost, R.D., Pierre, C., Sinninghe Damsté, J.S., Gottschal, J.C., Forney, L.J., Rouchy, J.M., 2002. $\mathrm{CH}_{4}$-consuming microorganisms and the formation of carbonate crusts at cold seeps. Earth and Planetary Science Letters 203, 195-203.

Aloisi, G., Pierre, C., Rouchy, J.M., Faugeres, J.C., Woodside, J., The MEDINAUT Scientific Party, 2000. Methane-related authigenic carbonates of eastern Mediterranean Sea mud volcanoes and their possible relation to gas hydrate destabilization. Earth and Planetary Science Letters 184, 321-338. 
Baker, P.A., Kastner, M., 1981, Constrationts on the formation of sedimentery dolomite. Science 213, 214-216.

Birgel, D., Elvert, M., Han, X.Q., Peckmann, J., 2008. ${ }^{13}$ C-depleted biphytanic diacids as tracers of past anaerobic oxidation of methane. Organic Geochemistry 39, 152-156.

Birgel, D., Feng, D., Roberts, H.H., Peckmann, J., 2011. Changing redox conditions at cold seeps as revealed by authigenic carbonates from Alaminos Canyon, northern Gulf of Mexico. Chemical Geology 285, 82-96.

Birgel, D., Peckmann, J., 2008. Aerobic methanotrophy at ancient marine methane seeps: A synthesis. Organic Geochemistry 39, 1659-1667.

Birgel, D., Thiel, V., Hinrichs, K.U., 2006. Lipid biomarker patterns of methane-seep microbialites from the Mesozoic convergent margin of Califonia. Organic Geochemistry 37, 1289-1302.

Blumenberg, M., Seifert, R., Reitner, J., Pape, T., Michaelis, W., 2004. Membrane lipid patterns typify distinct anaerobic methanotrophic consortia. Proceedings of the National Academy of Sciences of the United States of America 101, 11111-11116.

Blumenberg, M., Krüger, M., Nauhaus, K., Talbot, H. M., Oppermann, B., Seifert, R., Michaelis, W., 2006. Biosynthesis of hopanoids by sulfate-reducing bacteria (genus Desulfovibrio). Environmental Microbiology, 8(7), 1220-1227.

Blumenberg, M., Thiel, V., Riegel, W., Kah, L.C., Reitner, J., 2012. Biomarkers of black shales formed by microbial mats, Late Mesoproterozoic (1.1 Ga) Taoudeni Basin, Mauritania. Precambrian Research 196-197, 113-127.

Boetius, A., Ravenschlag, K., Schubert, C.J., Rickert, D., Widdel, F., Gieseke, A., Amann, R., Jorgensen, B.B., Witte, U., Pfannkuche, O., 2000. A marine microbial consortium apparently 
mediating anaerobic oxidation of methane. Nature 407, 623-626.

Burton, E.A., 1993. Controls on marine carbonate cement mineralogy: review and reassessment. Chemical Geology 105, 163-179.

Chen, D., Huang, Y., Yuan, X., Cathles III, L.M., 2005. Seep carbonates and preserved methane oxidizing archaea and sulfate reducing bacteria fossils suggest recent gas venting on the seafloor in the Northeastern South China Sea. Marine and Petroleum Geology 22, 613-621.

Chen, Z., Yan, W., Chen, M., Wang, S., Lu, J., Zheng, F., Xiang, R., Xiao, S., Yan, P., Gu, S., 2006. Discovery of cold seep carbonates in the northern continental slope of the South China Sea: new evidence for gas seeping activity. Chinese Science Bulletin 51, 1065-1072.

Chien, C.W., Huang, C.Y., Chen, Z., Lee, H., Harris, R., 2012. Miocene shallow-marine cold seep caronate in fold-and-thrust Western Foothills, SW Taiwan. Journal of Asian Earth Sciences 56, 200-211.

Chung, C.T., 1962. Geology of the Hunghuatzu anticline, Kaohsiung, Taiwan. Petroleum Geology of Taiwan 1, 31-50.

De Boever, E., Birgel, D., Thiel, V., Muchez, P., Peckmann, J., Dimitrov, L., Swennen, R., 2009. The formation of giant tubular concretions triggered by anaerobic oxidation of methane as revealed by archaeal molecular fossils (Lower Eocene, Varna, Bulgaria). Palaeogeography, Palaeoclimatology, Palaeoecology 280, 23-36.

Elvert, M., Boetius, A., Knittel, K., Jorgensen, B.B., 2003. Characterization of specific membrane fatty acids as chemotaxonomic markers for sulfate-reducing bacteria involved in anaerobic oxidation of methane. Geomicrobiology Journal 20, 402-419.

Elvert, M., Hopmans, E.C., Treude, T., Boetius, A., Suess, E., 2005. Spatial variations of 
methanotrophic consortia at cold methane seeps: implications from a high-resolution molecular and isotopic approach. Geobiology 3, 195-209.

Elvert, M., Suess, E., Whiticar, M.J., 1999. Anaerobic methane oxidation associated with marine gas hydrates: superlight $\mathrm{C}$ isotopes from saturated and unsaturated C20 and C25 irregular isoprenoids. Naturwissenschaften 86, 295-300.

Ge, L., Jiang, S., Swennen, R., Yang, T., Yang, J., Wu, N., Liu, J., Chen, D., 2010. Chemical environment of cold seep carbonate formation on the northern continental slope of South China Sea: Evidence from trace and rare earth element geochemistry. Marine Geology 277, 21-30.

Ge, L., Jiang, S., Yang, T., Yang, J., Wu, N, Zhang, G, Liu, J., 2011. Glycerol ethers biomarkers and carbon isotope composition in a cold seep carbonate chimney from Shenhu area, northern South China Sea. Chinese Science Bulletin 16, 1700-1707.

Guan, H., Sun, Y., Zhu, X., Mao, S., Feng, D., Wu, N., Chen, D., 2013. Factors controlling the types of microbial consortia in cold-seep environments: a molecular and isotopic investigation of authigenic carbonates from the South China Sea. Chemical Geology 354, 55-64.

Han, X., Suess, E., Huang, Y., Wu, N., Bohrmann, G., Su, X., Eisenhauer, A., Rehder, G., Fang, Y., 2008. Jiulong methane reef: Microbial mediation of seep carbonates in the South China Sea. Marine Geology 249, 243-256.

Heller, C., Blumenberg, M., Hoppert, M., Taviani, M., Reitner, J., 2012. Terrestrial mud volcanoes of the Salse di Nirano (Italy) as a window into deeply buried organic-rich shales of Plio-Pleistocene age. Sedimentary Geology 263-264, 202-209.

Hinrichs, K.U., Hayes, J.M., Sylva. S.P., Brewer, P.G., Delong, E.F., 1999. Methane-consuming archaebacteria in marine sediments. Nature 398, 802-805. 
Huang, C.Y., Chien, C.-W., Zhao, M., Li, H.-C., Iizuka, Y., 2006. Geological study of active cold seeps in the syn-collision accretionary prism Kaoping slope off SW Taiwan. Terrestrial, Atmospheric and Oceanic Sciences 17, 679-702.

Huang, C.-Y., Xia, K., Yuan, P.B., Chen, P.-G., 2001. Structural evolution from Paleogene extension to latest Miocene-Recent arc-continent collision offshore Taiwan: comparison with on land geology. Journal of Asian Earth Sciences 19, 619-639.

Huang, C.Y., Yuan, P.B., Lin, C.W., Wang, T.K., Chang, C.P., 2000. Geodynamic processes of Taiwan acr-continent collision and comparison with analogs in Timor, Papua New Guinea, Urals and Corsica. Tectonophysics 325, 1-21.

Knittel, K., Loekann, T., Boetius, A., Kort, R., Amann, R., 2005. Diversity and distribution of methanotrophic archaea at cold seeps. Applied and Environmental Microbiology 71, 467-479.

Koga, Y., Morii, H., Akagawa-Matsushita, M., Ohga, I., 1998. Correlation of polar lipid composition with 16S rRNA phylogeny in methanogens. Further analysis of lipid component parts. Bioscience, Biotechnology, and Biochemstry 62, 230-236.

Leefmann, T., Bauermeister, J., Kronz, A., Liebetrau, V., Reitner, J., Thiel, V., 2008. Miniaturized biosignature analysis reveals implications for the formation of cold seep carbonates at Hydrate Ridge (off Oregon, USA). Biogeosciences 5, 731-738.

Luff, R., Wallmann, K., 2003. Fluid flow, methane fluxes, carbonate precipitation and biogeochemical turnover in gas hydrate-bearing sediments at Hydrate Ridge, Cascadia Margin: numerical modeling and mass balances. Geochimica et Cosmochimica Acta 67, 3403-3421.

Michaelis, W., Seifert, R., Nauhaus, K., Treude, T., Thiel, V., Blumenberg, M., Knittel, K., Gieseke, A., Peterknecht, K., Pape, T., Boetius A., Amann, R., Jorgensen, B.B., Widdel, F., Peckmann, J., Pimenov, N.V., Gulin, M.B., 2002. Microbial reefs in the Black Sea fueled anaerobic oxidation of 
methane. Science 297, 1013-1015.

Niemann, H., Duarte, J., Hensen, C., Omoregie, E., Magalhaes, V.H., Elvert, M., Pinheiro, L.M., Kopf, A., Boetius, A., 2006. Microbial methane turnover at mud volcanoes of the Gulf of Cadiz. Geochimica et Cosmochimica Acta 70, 5336-5355.

Niemann, H., Elvert, M., 2008. Diagnostic lipid biomarker and stable carbon isotope signatures of microbial communities mediating the anaerobic oxidation of methane with sulphate. Organic Geochemistry 39, 1668-1677.

Orphan, V.J., Hinrichs, K.U., Ussler, W., Paull, C.K., Taylor, L.T., Sylva, S.P., Hayes, J.M., Delong, E.F., 2001. Comparative analysis of methane oxidizing archaea and sulfate-reducing bacteria in anoxic marine sediments. Applied and Environmental Microbiology 67, 1922-1934.

Pancost, R.D., Bouloubassi, I., Aloisi, G., Sinninghe Damste, J.S., The Medinaut shipboard scientific party, 2001. Three series of non-isoprenoidal dialkyl glycerol diethers in cold-seep carbonate crusts. Organic Geochemistry 32, 695-707.

Pancost, R.D., Sinninghe Damste, J.S., de Lint, S., van der Maarel, M.J.E.C., Gottschal, J.C., The MEDINAUT shipboard scientific party, 2000. Biomarker evidence for widespread anaerobic methane oxidation in Mediterranean sediments by a consortium of methanogenic archaea and bacteria. Applied and Environmental Microbiology 66, 1126-1132.

Pape, T., Blumenberg, M., Seifert, R., Egorov, V.N., Gulin, S.B., Walter, M., 2005. Lipid geochemistry of ethane-seep-related Black Sea carbonates. Palaeogeography, Palaeoclimatology, Palaeoecology 227, 31-47.

Peckmann, J., Birgel, D., Kiel, S., 2009. Molecular fossils reveal fluid composition and flow intensity at a Cretaceous seep. Geology $37,847-850$. 
Peckmann, J., Reimer, A., Luth, U., Luth, C., Hansen, B.T., Heinicke, C., Hoefs, J., Reitner, J., 2001. Methane-derived carbonates and authigenic pyrite from the northwestern Black Sea. Marine Geology 177, 129-150.

Peckmann, J., Thiel, V., 2004. Carbon cycling at ancient methane-seeps. Chemical Geology 205, 443-467.

Reitner, J., Peckmann, J., Blumenberg, M., Michaelis, W., Reimer, A., Thiel, V., 2005. Concretionary methane-seep carbonates and associated microbial communities in Black Sea sediments. Palaeogeography, Palaeoclimatology, Palaeoecology 227, 18-30.

Ritger, S., Carson, B., Suess, E., 1987. Methane-derived authigenic carbonates formed by subduction-induced pore-water expulsion along the Oregon/Washington margin. Geological Society of America Bulletin 98, 147-156.

Rohmer, M., Bouvier-Navé, P., Ourisson, G., 1984. Distribution of hopanoid triterpenes in prokaryotes. Journal of General Microbiology 130, 1137-1150.

Savard, M.M., Beauchamp, B., Veizer, J., 1996. Significance of aragonite cements around Cretaceous marine methane seeps. Journal of Sedimentary Research 66, 430-438.

Stadnitskaia, A., Baas, M., Ivanov, M.K., van Weering, T.C.E., Sinninghe Damsté, J.S., 2003. Novel archaeal macrocyclic diether core membrane lipids in a methane-derived carbonate crust from a mud volcano in the Sorokin Trough, NE Black Sea. Archaea 1, 165-173.

Stadnitskaia, A., Bouloubassi, I., Elvert, M., Hinrichs, K.U., Sinninghe Damsté, J.S., 2008. Extended hydroxyarchaeol, a novel lipid biomarker for anaerobic methanotrophy in cold seepage habitats. Organic Geochemistry 39, 1007-1014.

Stakes, D.S., Orange, D., Paduan, J.B., Salamy, K.A., Maher, N., 1999. Cold-seeps and authigenic 
carbonate formation in Monterey Bay, California. Marine Geology 159, 93-109.

Suess, E., 2005. RV SONNE cruise report SO 177, Sino-German cooperative project, South China Sea Continental Margin: geological methane budget and environmental effects of methane emissions and gashydrates. IFM-GEOMAR Reports (http://store.pangaea.de/documentation/ Reports/SO177.pdf).

Sun, M., Wang, H., Liao, J., Gan, H., Xiao, J., Ren, J., Zhao, S., 2014. Sedimentary characteristics and model of gravity flow depositional system for the first member of upper Miocene Huangliu Formation in Dongfang area, Yinggehai Basin, northwestern South China Sea. Journal of Earth Science, 25(3), 506-518.

Sung, Q., Lin, C.-W., Lin, W.-H., Lin, W.-C., 2000. Explanatory text of the geologic map of Taiwan scale 1:50,000; Sheet 51 Chiahsien.

Thiel, V., Peckmann, J., Richnow, H.H., Luth, U., Reitner, J., Michaelis, W., 2001. Molecular signals for anaerobic methane oxidation in Black Sea seep carbonates and a microbial mat. Marine Chemistry 73, 97-112.

Ting, H.H., Huang, C.Y., Wu, L.C., 1991. Paleoenvironments of the Late Neogene sequences along the Nantzuhsien River, southern Taiwan. Petroleum Geology of Taiwan 26, 121-149.

Tong, H., Feng, D., Cheng, H., Yang, S., Wang, H., Min, A.G., Edwards, R.L., Chen, Z., Chen, D., 2013. Authigenic carbonates from seeps on the northern continental slope of the South China Sea: new insights into fluid sources and geochronology. Marine and Petroleum Geology 43, 260-271.

Torres, M.E., Mcmanus, J., Hammond, D.E., de Angelis, M.A., Heeschen, K.U., Colbert, S.L., Tryon, M.D., Brown, K.M., Suess, E., 2002. Fluid and chemical fluxes in and out of sediments hosting methane hydrate deposits on Hydrate Ridge, OR, I: hydrological provinces. Earth and Planetary Science Letters 201, 525-540. 
Xu, W., Yan, W., Chen, Z., Chen, H., Huang, W., Lin, H., 2014. Organic matters and lipid biomarkers in surface sediments from the northern South China Sea: Origins and transport. Journal of Earth Science, 25(1), 189-196.

Yu, X.G., Han, X.Q., Li, H.L., Jin, X.B., Gong, J.M., Suess, E., Huang, Y.Y., Wu, N.Y., Su, X., 2008. Biomarkers and carbon isotope composition of anaerobic oxidation of methane in sediments and carbonates of northeastern part of Dongsha, South China Sea. Acta Oceanologica Sinica 30, 77-84 (in Chinese with English abstract).

Zhang, H., Yang, S., Wu, N., Schultheiss, P., GMGS-1 science team, 2007. China's first gas hydrate expedition successful. Fire in the Ice: Methane Hydrate Newsletter, National Energy Technology Laboratory, U.S Department of Energy, Spring/Summer issue, 1. 


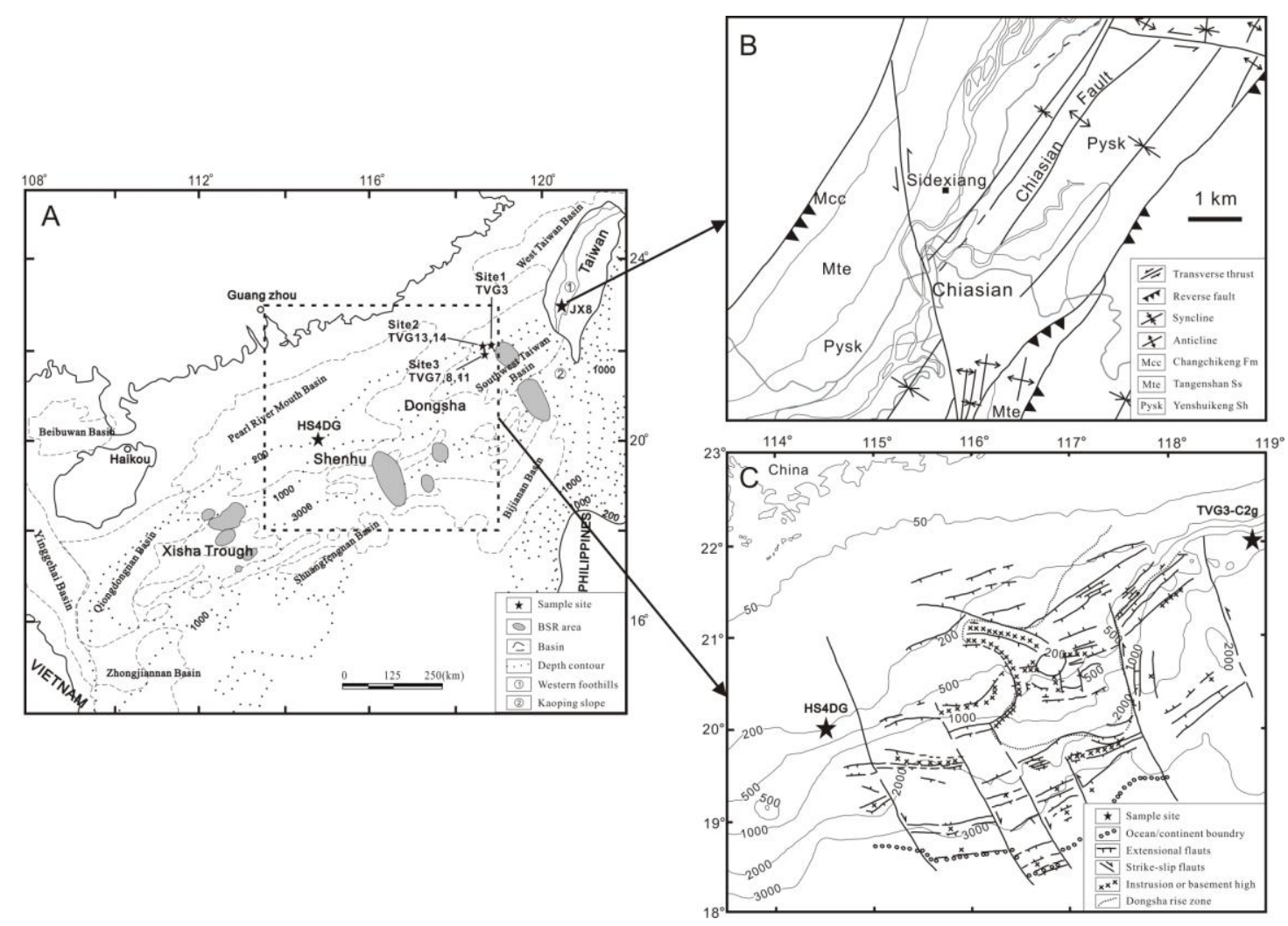

Figure 1 

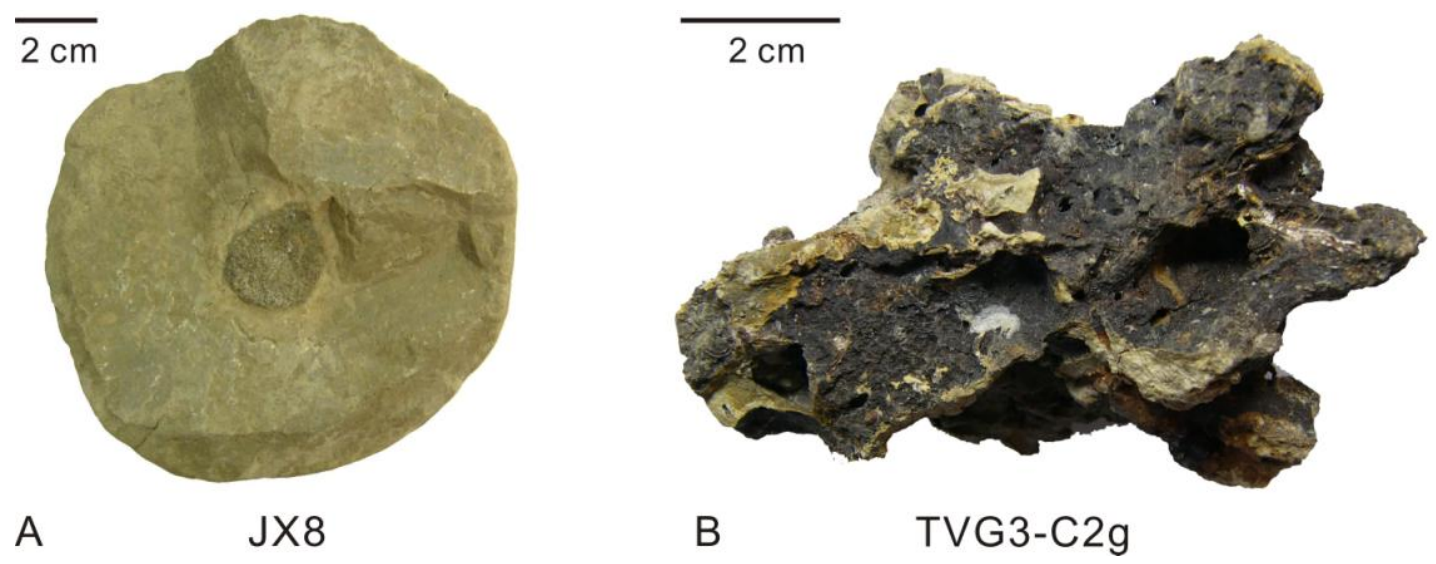

Figure 2 


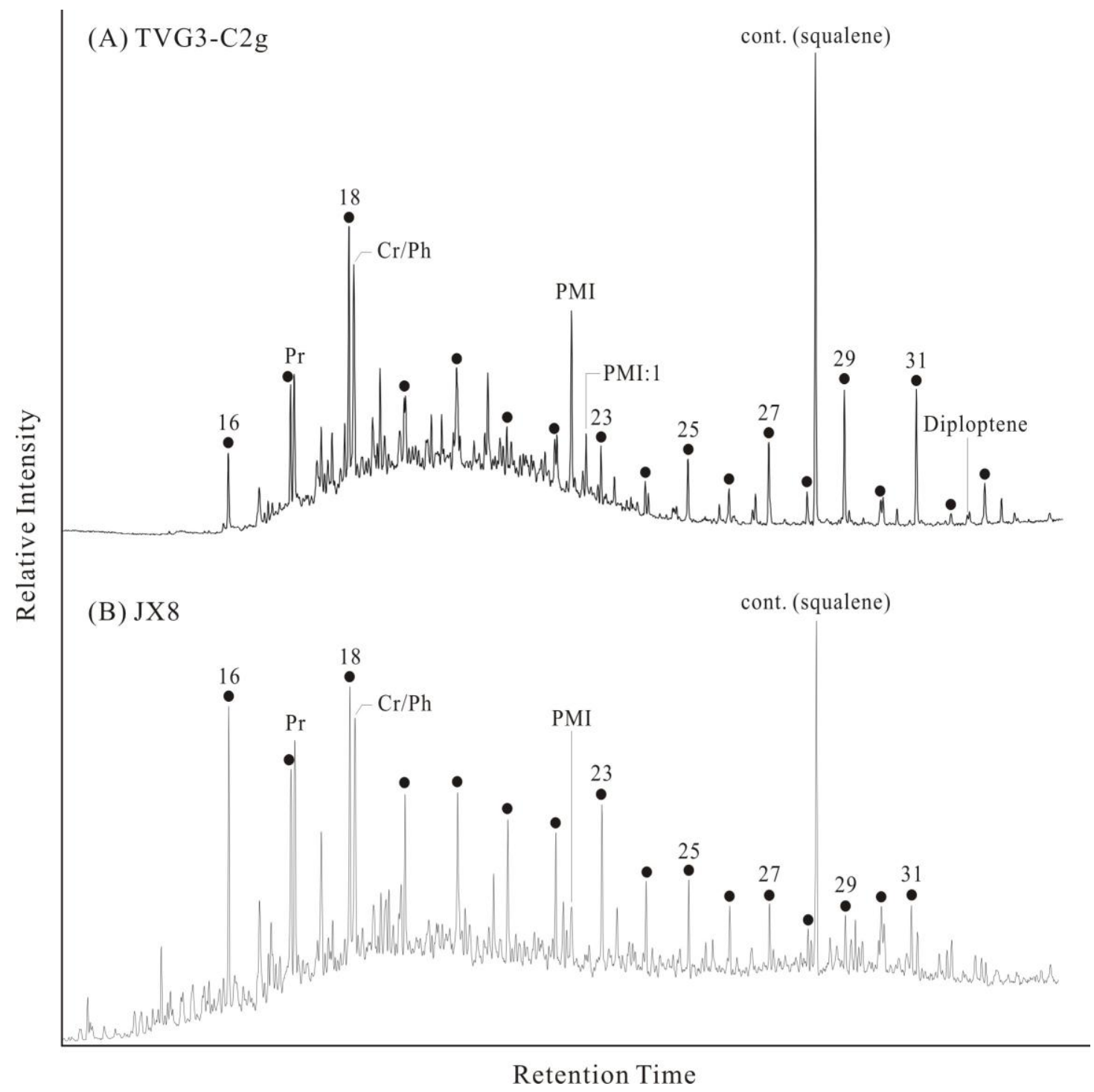

Figure 3 


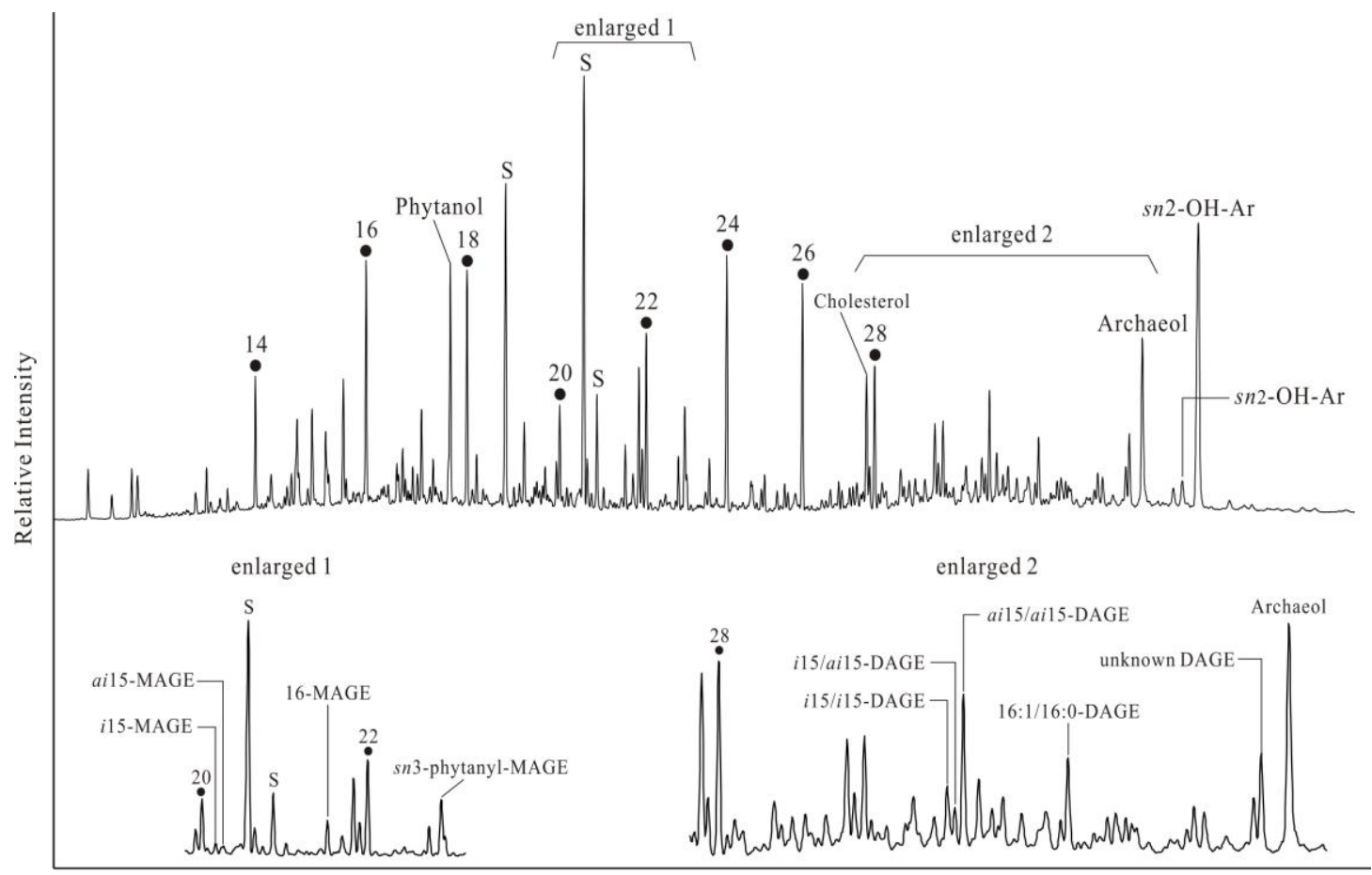

Retention Time

Figure 4 


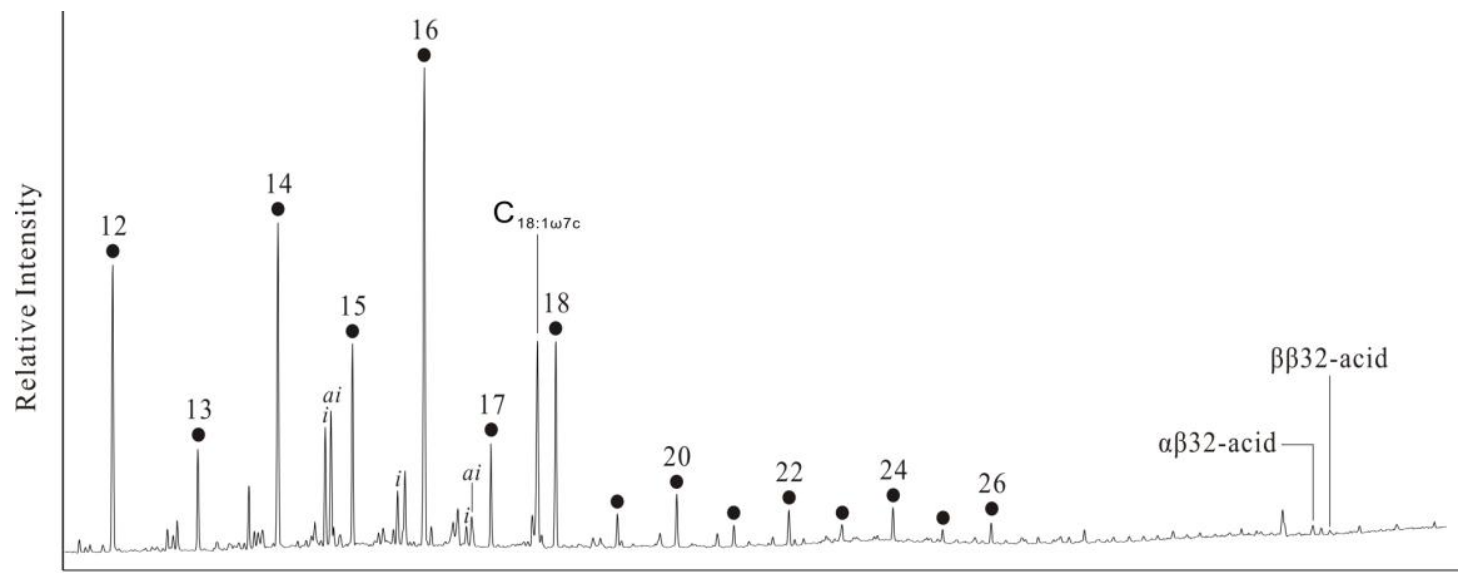

Retention Time

Figure 5 


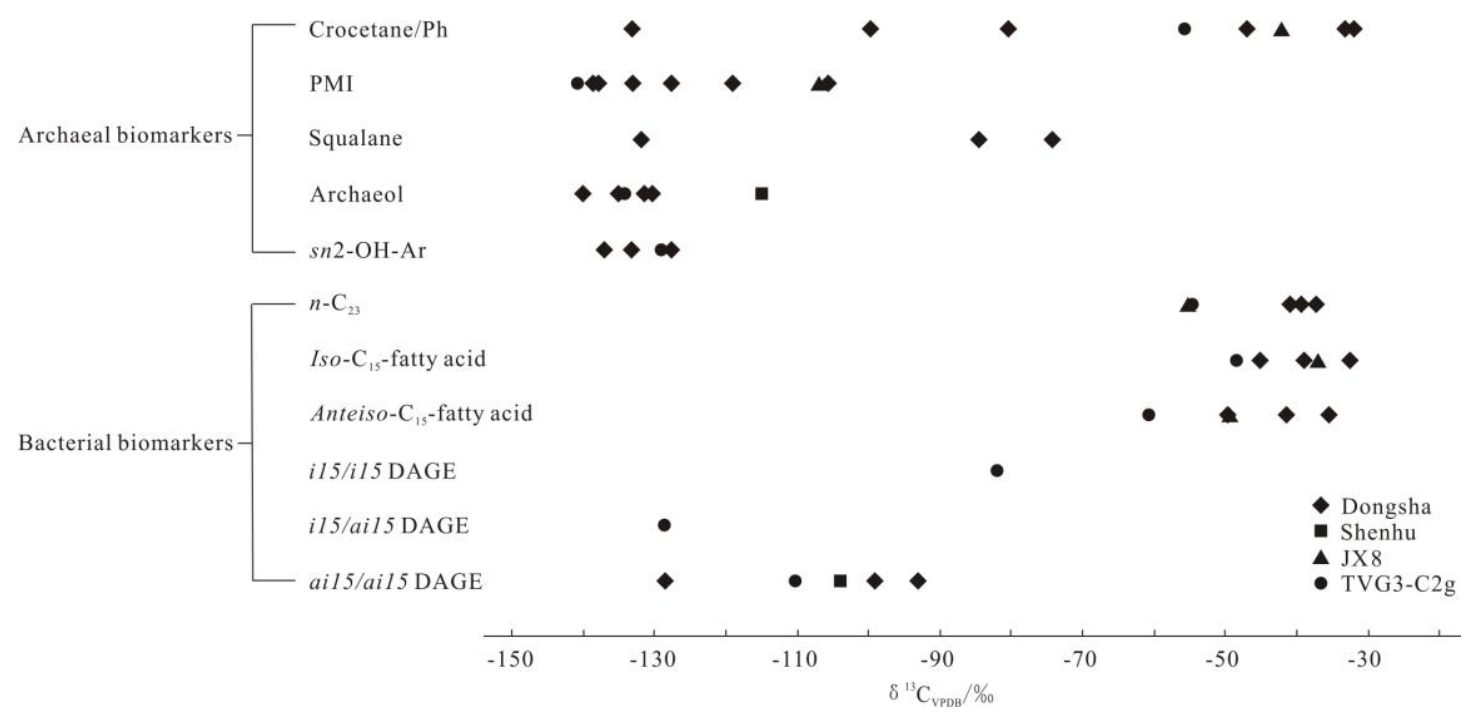

Figure 6 


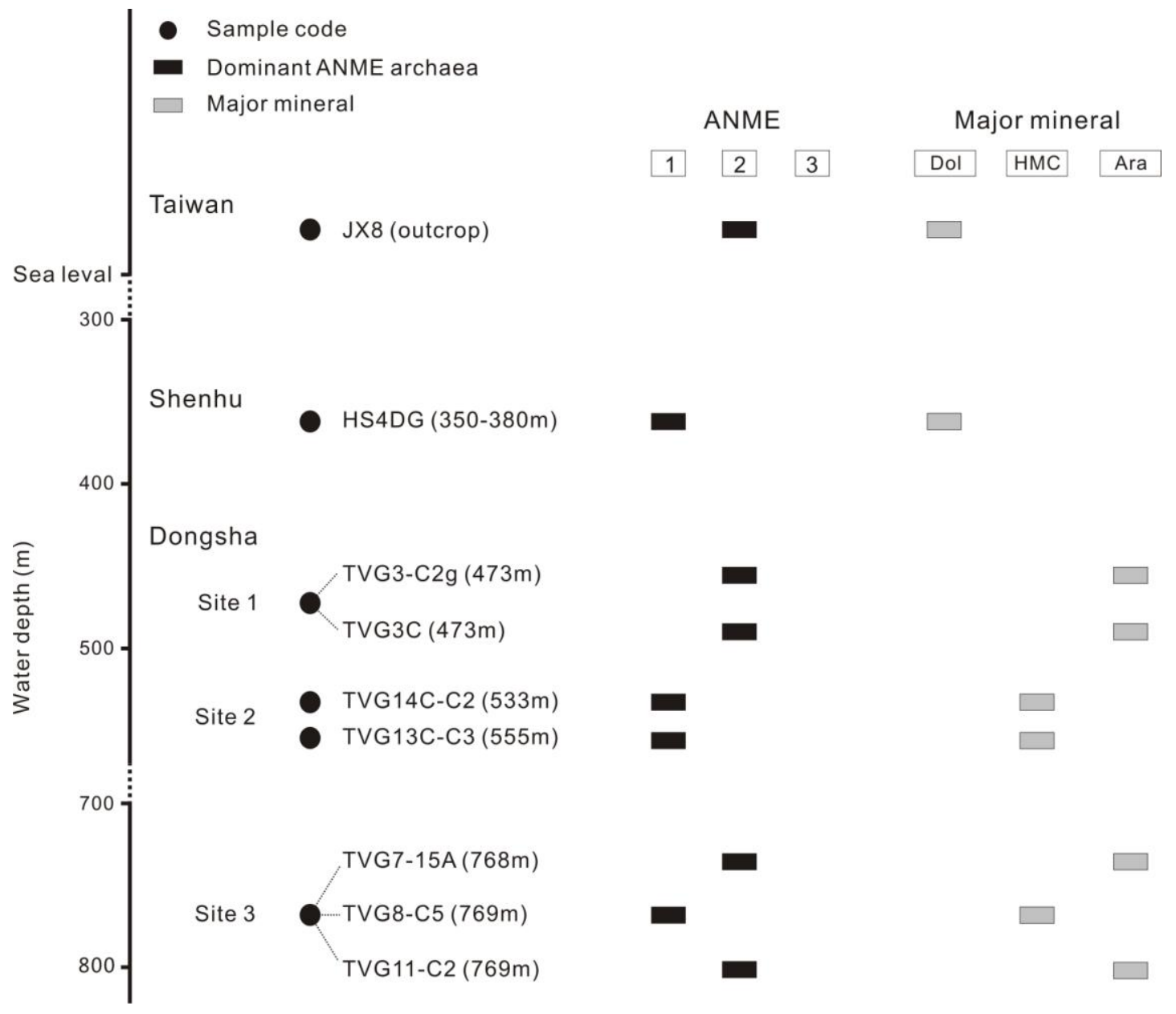

Figure 7 
Table 1 Location and description of cold seep carbonates from Chiasian, Dongsha and Shenhu.

\begin{tabular}{lllllll}
\hline Location & Sample code & Latitude (N) & Longitude (E) & Water depth (m) & Description & References \\
\hline Chiasian & JX8 & - & - & outcrop & Chimney & This study \\
Dongsha-Site 1 & TVG3-C2g & $22^{\circ} 08.96^{\prime}$ & $118^{\circ} 52.34^{\prime}$ & 473 & Crust & This study \\
& TVG3C & $22^{\circ} 08.96^{\prime}$ & $118^{\circ} 52.34^{\prime}$ & 473 & Massive & Han et al., 2008 \\
Dongsha-Site 2 & TVG13C-C3 & $22^{\circ} 08.54^{\prime}$ & $118^{\circ} 43.45^{\prime}$ & 555 & Crust & Tong et al., 2013; Guan et al., 2013 \\
& TVG14C-C2 & $22^{\circ} 08.63^{\prime}$ & $118^{\circ} 43.39^{\prime}$ & 533 & Concretion & Han et al., 2013; Guan et al., 2013 \\
Dongsha-Site 3 & TVG7-15A & $22^{\circ} 02.83^{\prime}$ & $118^{\circ} 46.54^{\prime}$ & 768 & Chemoherm & Han et al., 2008 \\
& TVG8-C5 & $22^{\circ} 02.85^{\prime}$ & $118^{\circ} 46.55^{\prime}$ & 769 & Concretion & Han et al., 2008; Guan et al., 2013 \\
& TVG11-C2 & $22^{\circ} 02.86^{\prime}$ & $118^{\circ} 46.51^{\prime}$ & 769 & Concretion & Han et al., 2008;
\end{tabular}


Table 2 Mineralogy and $\delta^{13} \mathrm{C}$ values of cold seep carbonates from Chiasian, Dongsha and Shenhu.

\begin{tabular}{|c|c|c|c|c|}
\hline Location & Sample code & Major mineral & $\begin{array}{l}\delta^{13} \mathrm{C}_{\text {carbonate }} \\
(\%, \mathrm{VPDB})\end{array}$ & References \\
\hline Chiasian & $\mathrm{JX} 8$ & Dolomite & -24.0 & This study \\
\hline \multirow[t]{2}{*}{ Dongsha- Site 1} & TVG3-C2g & Aragonite & -50.9 & This study \\
\hline & TVG3C & Aragonite & -48.9 to -35.7 & Han et al., 2008 \\
\hline \multirow[t]{2}{*}{ Dongsha- Site 2} & TVG13C-C3 & HMC & -48.9 to -41.2 & Tong et al., 2013; Guan et al., 2013 \\
\hline & TVG14C-C2 & HMC & -56.3 to -47.8 & Han et al., 2013; Guan et al., 2013 \\
\hline \multirow[t]{3}{*}{ Dongsha- Site 3} & TVG7-15A & Aragonite & -52.0 & Han et al., 2008 \\
\hline & TVG8-C5 & HMC & -51.3 to -48.3 & Han et al., 2008; Guan et al., 2013 \\
\hline & TVG11-C2 & HMC & -57.6 to -51.2 & Han et al., 2008; \\
\hline Shenhu & HS4DG & Dolomite & -40.2 to -38.7 & Ge et al., 2011; Tong et al., 2013 \\
\hline
\end{tabular}


Table $3 \delta^{13} \mathrm{C}$ values (\%o, VPDB) of archaeal and bacterial biomarkers in cold seep carbonates.

\begin{tabular}{|c|c|c|c|c|c|c|c|c|c|}
\hline & JX8 & TVG3-C2g & TVG3C & TVG13C-C3 & TVG14C-C2 & TVG7-15A & TVG8-C5 & TVG11-C2 & HS4DG \\
\hline ANME & 2 & 2 & 2 & 1 & 1 & 1 & 1 & 1 & 1 \\
\hline \multicolumn{10}{|l|}{ Archaeal biomarkers } \\
\hline Crocetane/Ph & -42.0 & -55.6 & -80.4 & -32.0 & -33.2 & -99.6 & -47.0 & -133.0 & - \\
\hline PMI & -106.9 & -140.8 & -105.7 & -138.7 & -127.6 & -119.0 & -137.8 & -133.0 & - \\
\hline Squalane & - & - & -74.2 & - & - & -84.5 & -131.8 & - & - \\
\hline Archaeol & - & -134.3 & - & -140.0 & -130.2 & & -131.4 & -135.0 & -115.0 \\
\hline$s n 2-\mathrm{OH}-\mathrm{Ar}$ & - & -129.0 & - & -133.2 & - & - & -127.6 & -137.0 & - \\
\hline sn2-OH-Ar/Ar & - & $>1$ & - & 1.3 & 0.3 & - & 0.4 & - & 0 \\
\hline \multicolumn{10}{|l|}{ Bacterial biomarkers } \\
\hline$n-\mathrm{C}_{23}$ & -55.2 & -54.7 & - & -40.8 & -37.2 & - & -39.4 & - & - \\
\hline Iso- $\mathrm{C}_{15}$-fatty acid & -37.0 & -48.3 & - & -45.2 & -32.5 & - & -38.9 & - & - \\
\hline Anteiso- $\mathrm{C}_{15}$-fatty acid & -49.4 & -60.6 & - & -49.8 & -35.5 & - & -41.5 & - & - \\
\hline i15/i15 DAGE & - & -81.9 & - & - & - & - & - & - & - \\
\hline i15/ai15 DAGE & - & -128.6 & - & - & - & - & - & - & - \\
\hline ai15/ai15 DAGE & - & -110.2 & - & -128.5 & -99.1 & - & -93.0 & - & -104.0 \\
\hline \multicolumn{10}{|c|}{ Other ${ }^{13} \mathrm{C}$-depleted biomarkers } \\
\hline$n-\mathrm{C}_{14}$ & -31.2 & -32.8 & - & -40.8 & -37.2 & - & -39.4 & - & - \\
\hline References & This study & This study & $\begin{array}{l}\text { Yu et al., } \\
2007\end{array}$ & $\begin{array}{l}\text { Guan et al., } \\
2013\end{array}$ & $\begin{array}{l}\text { Guan et al., } \\
2013\end{array}$ & $\begin{array}{l}\text { Yu et al., } \\
2007\end{array}$ & $\begin{array}{l}\text { Guan et al., } \\
2013\end{array}$ & $\begin{array}{l}\text { Birgel et al., } \\
2008\end{array}$ & $\begin{array}{l}\text { Ge et al., } \\
2011\end{array}$ \\
\hline
\end{tabular}

- signs denote the absence of a compound 